\title{
Calculation of $\mathrm{HNO}_{2}$ Concentration from Redox Potential in $\mathrm{HNO}_{3}-\mathrm{H}_{2} \mathrm{O}$ System as an Aid to Understanding the Cathodic Reaction of Nitric Acid Corrosion
}

\author{
Masayuki Takeuchi* and G. O. H. Whillock** \\ * Tokai Works, Japan Nuclear Cycle Development Institute \\ ${ }^{* *}$ Sellafield, British Nuclear Fuels plc.
}

\begin{abstract}
Nitrous acid affects the corrosion of metals such as stainless steels in nitric acid. However nitrous acid is not particularly stable in nitric acid and the analytical methods available are quite involved. Accordingly, the calculation of nitrous acid concentration from redox potential was tested in the $\mathrm{HNO}_{3}-\mathrm{H}_{2} \mathrm{O}$ system as a convenient in situ analysis method. The calculation process is based on Nernst's equation and the required thermodynamic data were obtained from published values. The available thermodynamic data allow calculation of nitrous acid concentration from $273 \mathrm{~K}$ to $373 \mathrm{~K}$ for $0 \%-100 \% \mathrm{HNO}_{3}$. The redox potential was measured in $8 \mathrm{kmol} \cdot \mathrm{m}^{-3} \mathrm{HNO}_{3}$ under NO bubbling and the nitrous acid concentration was determined by a Colourimetric method. The calculated data were compared with the measured data and a good agreement was found. It was found that the corrosion potential of stainless steel is influenced by nitrous acid concentration in nitric acid solution. The calculation process is useful for in-situ analysis of nitrous acid species in $\mathrm{HNO}_{3}-\mathrm{H}_{2} \mathrm{O}$ system and understanding the behavior of the cathodic reaction associated with nitric acid corrosion.
\end{abstract}

Key words : nitrous acid, in-situ analysis, nitric acid corrosion, stainless steel, cathodic reaction, thermodynamic calculation, redox potential

\section{Introduction}

Corrosion is an electrochemical process which consists of anodic (i. e. oxidation) and cathodic (i.e. reduction) reactions. In general, the anodic reaction is influenced by material factors, whilst the cathodic reaction is influenced by environmental factors. In the nitric acid system, the over-all cathodic reaction is known to be ${ }^{1)}$ :

$$
\mathrm{NO}_{3}^{-}+3 \mathrm{H}^{+}+2 \mathrm{e}^{-}=\mathrm{HNO}_{2}+\mathrm{H}_{2} \mathrm{O}
$$

Nitric acid corrosion of stainless steel is strongly affected by the cathodic reaction, since in sufficiently oxidising conditions (ie. those for which the solutions exerts a high redox potential), the passivity of stainless steel breaks down and significant transpassive corrosion rates can be generated ${ }^{2)}$. Nitrous acid $\left(\mathrm{HNO}_{2}\right)$, which is the product of nitrate reduction (reaction (1)), exerts a powerful effect on the redox potential of nitric acid solutions owing to the fact that reaction (1) actually consists of a series of linked steps involving $\mathrm{HNO}_{2}$ and the reaction is autocatalytic ${ }^{1}$. However it is difficult to understand the behaviour of $\mathrm{HNO}_{2}$ which is one of the species in the above reaction because it is not particularly stable in nitric acid. In this paper, the nitrous acid concentration in nitric acid solutions was calculated from redox potential by application of Nernst's equation and the results obtained were compared with direct measure-

* 4-33, Muramatsu, Tokai-mura, Naka-gun, Ibaraki-ken, 319-1194 Japan)

** Sellafield, Seascale, Cumbria, England, CA20 1PG ment. In addition, the effect of $\mathrm{HNO}_{2}$ concentration on the corrosion potential of stainless steel was investigated in $\mathrm{HNO}_{3}$ solution.

\section{Thermodynamic theory}

Nernst's equation can be used to relate the concentration of nitrous acid in nitric acid to the solution redox potential ${ }^{3}$. According to the equation, when the activity coefficient of $\mathrm{HNO}_{2}$ is assumed to be unity (which is not unreasonable because of the expected low concentration of $\mathrm{HNO}_{2}$ ), the electrode potential $E$ for reaction (1) is given by:

$E=E^{0}+(R T / 2 F) \ln \left\{\left[\mathrm{H}^{+}\right]^{3}\left[\mathrm{NO}_{3}{ }^{-}\right] \Upsilon_{ \pm}{ }^{4} /\left[\mathrm{HNO}_{2}\right] a_{\mathrm{L}}\right\}$

$$
E^{0}=1 / 2 F\left(\mu_{\mathrm{NO}_{3}^{-}}^{\circ}+3 \mu_{\mathrm{H}^{+}}^{\circ}-\mu_{\mathrm{HNO}_{2}}^{\circ}-\mu_{\mathrm{H}_{2} \mathrm{O}}^{\circ}\right)
$$

where $E^{0}$ is the standard equilibrium potential, $\left[\mathrm{H}^{+}\right]$, $\left[\mathrm{NO}_{3}{ }^{-}\right]$and $\left[\mathrm{HNO}_{2}\right]$ are the molality of each ion or compound (mol $/ \mathrm{kg}$-water), $R$ is the gas constant (= $1.986 \mathrm{cal} / \mathrm{mol} \cdot \mathrm{K}), F$ is Faraday's constant $(=23060$ $\mathrm{cal} / \mathrm{V}), \mu^{\circ}$ is the chemical potential of each species (cal $/ \mathrm{mol}) . \gamma_{ \pm}$is the mean activity coefficient of a pure aqueous solution of $\mathrm{HNO}_{3}$ and $a_{\mathrm{L}}$ is the water activity of a pure aqueous solution $\mathrm{HNO}_{3}$.

Therefore, if $\mu^{\circ}, \gamma_{ \pm}$and $a_{\mathrm{L}}$ are known for a certain $\mathrm{HNO}_{3}$ concentration, $\left[\mathrm{HNO}_{2}\right]$ can be theoretically calculated from the measured solution redox potential and vice versa.

\subsection{Calculations of $\boldsymbol{\mu}^{\circ}$ and $\boldsymbol{E}^{0}$}

In this work, the calculated data of chemical potentials at $373 \mathrm{~K}$ published by EPRI ${ }^{4)}$ were used to calcu- 
Table 1 Chemical potentials at $298 \mathrm{~K}$ and $373 \mathrm{~K}$.

\begin{tabular}{cccccc}
\hline & $\mathrm{NO}_{3}{ }^{-}($aq., $\mathrm{m}=1)$ & $\mathrm{H}^{+}($aq., $\mathrm{m}=1)$ & $\mathrm{HNO}_{2}$ (aq., m=1) & $\mathrm{H}_{2} \mathrm{O}$ (liq.) & $\mathrm{H}_{2}$ (g) \\
\hline$\mu^{\circ}{ }_{298 K}[\mathrm{~kJ} / \mathrm{mol}]$ & $-111,389$ & 0 & $-55,674$ & $-237,292$ & 0 \\
$\mathrm{G}^{\circ}{ }_{373 \mathrm{~K}}[\mathrm{~kJ} / \mathrm{mol}]$ & $-122,001$ & +435 & $-65,733$ & $-243,198$ & $-10,051$ \\
\hline
\end{tabular}

late $E^{0}$ from equation (3). $\mu^{\circ}$ at $298 \mathrm{~K}$ and $G^{0}$ at $373 \mathrm{~K}$ are shown in Table 1. $G^{0}$ shows Gibb's free energy and it needs to consider equation (4) in addition to equation (3) to apply $G^{0}$ at $373 \mathrm{~K}$ in the table to the calculation of $E^{0}$ (vs. NHE). Accordingly, $E^{0}$ at $373 \mathrm{~K}$ is calculated by equation (5).

$$
\begin{aligned}
& 2 \mathrm{H}^{+}+2 \mathrm{e}^{-}=\mathrm{H}_{2}(\mathrm{~g}) \\
& E^{0}=1 / 2 F\left(G_{\mathrm{NO}_{3}^{-}}^{0}+G_{\mathrm{H}^{+}}^{0}+G_{\mathrm{H}_{2}}^{0}-G_{\mathrm{HNO}_{2}}^{0}-G_{\mathrm{H}_{2} \mathrm{O}}^{0}\right)
\end{aligned}
$$

Assuming that enthalpy and entropy are linearly related to temperature, $E^{0}$ in the range from $273 \mathrm{~K}$ to $373 \mathrm{~K}$ was calculated from equation (6).

$$
E^{0}{ }_{T}=E^{0}{ }_{298 \mathrm{~K}}+\left(\left(E^{0}{ }_{373 \mathrm{~K}}-E^{0}{ }_{298 \mathrm{~K}}\right) / 75\right) *(T-298)
$$

\subsection{Calculations of $a_{\mathrm{L}}$ and $\boldsymbol{r}_{ \pm}$}

In order to calculate $a_{\mathrm{L}}$ and $\Upsilon_{ \pm}$, Clegg and Brimblecombe's data were used ${ }^{5)}$. They presented values for $a_{\mathrm{L}}$ and $\gamma_{ \pm}$in the range from $273 \mathrm{~K}$ to $373 \mathrm{~K}$ for $0 \%-100 \%$ $\mathrm{HNO}_{3}$ as a function of total mole fraction of ions $\left(X_{\mathrm{i}}\right)$.

In their paper, $a_{\mathrm{L}}$ and $\gamma_{ \pm}$at $298 \mathrm{~K}$ are expressed by equations $(7)-(9)$ :

$$
f_{ \pm}=r_{ \pm}\left(1+\left(M_{1} / 1000\right) \sum m_{i}\right)
$$

where $f_{ \pm}$is the mean activity coefficient at $298 \mathrm{~K}$ expressed as a molar fraction and $\gamma_{ \pm}$is the mean activity coefficient at $298 \mathrm{~K}$ expressed as a weight concentration. $M_{1}$ is the molar mass of the solvent (18. $0152 \mathrm{~g}$ for $\mathrm{H}_{2} \mathrm{O}$ ). $\sum m_{i}$ means the summation of over all solute species $i$. In this case, $\sum m_{i}$ equals $m\left[\mathrm{H}^{+}\right]+m\left[\mathrm{NO}_{3}^{-}\right]$, where $m$ is molality (i.e. $\mathrm{mol} / \mathrm{kg}$ $\left.\mathrm{H}_{2} \mathrm{O}\right)$.

$$
\begin{aligned}
\ln \left(f_{ \pm}\right)= & -A_{x}\left\{(2 / \omega) \ln \left(1+\omega I_{x}{ }^{1 / 2}\right)\right. \\
& \left.+\left(I_{x}^{1 / 2}-2 I_{x}^{3 / 2}\right) /\left(1+\omega I_{x}^{1 / 2}\right)\right\} \\
& +X_{\mathrm{I}}^{2}\left(W+2 X_{\mathrm{I}} U+X_{\mathrm{I}}^{2} V\right)-W \\
\ln \left(a_{\mathrm{L}}\right)= & \ln \left(X_{\mathrm{L}}\right)+2 A_{x} I_{x}^{3 / 2} /\left(1+\omega I_{x}^{1 / 2}\right) \\
& +X_{\mathrm{I}}^{2}\left[\left\{W+\left(2 X_{\mathrm{I}}-1\right) U\right\}-V X_{\mathrm{I}}\left(X_{\mathrm{I}}-1 / 3\right)\right]
\end{aligned}
$$

where $A_{x}$ is the Debye-Hückel constant $(=2.917$ at $298 \mathrm{~K}) . X_{\mathrm{I}}$ means total mole fraction of ions $(X$ $\left[\mathrm{H}^{+}\right]=X\left[\mathrm{NO}_{3}{ }^{-}\right]=n\left[\mathrm{H}^{+}\right] /\left(n\left[\mathrm{H}^{+}\right]+n\left[\mathrm{NO}_{3}{ }^{-}\right]+n\right.$ $\left.\left[\mathrm{H}_{2} \mathrm{O}\right]\right), \quad n$ : mole number) and $I_{x}$ means ionic strength $\left(=1 / 2\left(X\left[\mathrm{H}^{+}\right]+X\left[\mathrm{NO}_{3}^{-}\right]\right) . \omega, W, U\right.$ and $V$ are constants and their values are shown in Table $2^{5)}$.
Table 2 Each value of parameters for calculation of activity coefficient.

\begin{tabular}{ccccc}
\hline & $\omega$ & $W$ & $U$ & $V$ \\
\hline Value & 14.065 & -3.82721 & 0.202749 & -2.57620 \\
Standard error & 0.368 & 0.0193 & 0.0498 & 0.231 \\
\hline
\end{tabular}

$a_{\mathrm{L}}$ and $\Upsilon_{ \pm}$in the range from $273 \mathrm{~K}$ to $373 \mathrm{~K}\left(=\Upsilon_{ \pm, T}\right.$, $a_{\mathrm{L}, T}$ ) were calculated by using $a_{\mathrm{L}}$ and $\gamma_{ \pm}$at $298 \mathrm{~K}$ on the basis of the following equations:

$$
\log \left(f_{ \pm, T}\right)=\log \left(f_{ \pm}\right)+(y / v) L_{2}-(z / v) J_{2}+(\Omega / v) \Gamma_{2}
$$

$$
\log \left(a_{\mathrm{L}, T}\right)=\log \left(a_{\mathrm{L}}\right)+y / L_{1}-z / J_{1}+\Omega \Gamma_{1}
$$
where

$$
\begin{aligned}
& y=\left(T_{\mathrm{r}}-T\right) /\left(2.303 R T_{\mathrm{r}} T\right) \quad T_{\mathrm{r}}: 25\left({ }^{\circ} \mathrm{C}\right) \\
& z=T_{\mathrm{r}} y-\log \left(T_{\mathrm{r}} / T\right) / R \\
& \Omega=T_{\mathrm{r}}\left(z+1 / 2\left(T-T_{\mathrm{r}}\right) y\right) \\
& \Gamma_{2}=1.7722 X_{\mathrm{I}}\left(X_{\mathrm{I}}-2\right)-0.35496 X_{\mathrm{I}}^{2.5}\left(5 X_{\mathrm{I}}-7\right)
\end{aligned}
$$

$$
\Gamma_{1}=X_{\mathrm{I}}^{2}\left(0.8861-0.8874 X_{\mathrm{I}}^{1.5}\right)
$$

$L_{2}, L_{1}, J_{2}$ and $J_{1}$ were calculated on the basis of Clegg and Brimblecombe's data ${ }^{5}$. The Tables list the Chebyshev polynomial coefficients for the calculation of the partial molal functions $L_{2}, L_{1}, J_{1}$ and $J_{1}$ for $0 \leq X_{I} \leq 1$. 0 . Data fitting was carried out as a function of $I_{x}{ }^{1 / 2}$ and the variable $X$ was defined by the following equation.

$$
X=I_{x}^{1 / 2}
$$

The polynomial is represented in Chebyshev series form by the normalised variable $\alpha$ :

$$
\alpha=\left(2 X-X_{\max }-X_{\min }\right) /\left(X_{\max }-X_{\min }\right)
$$

where $X_{\max }$ and $X_{\min }$ are the upper and lower limits of the fit respectively (given in each table). The polynomial representation, with $\mathrm{N}+1$ coefficients, of each partial molal function $f(\alpha)$ is given by

$$
\begin{aligned}
f(\alpha)= & 0.5 \alpha_{0} T_{0}(\alpha)+\alpha_{1} T_{1}(\alpha)+\alpha_{2} T_{2}(\alpha) \\
& +\alpha_{3} T_{3}(\alpha)+\cdots+\alpha_{\mathrm{N}} T_{\mathrm{N}}
\end{aligned}
$$

where $T_{0}(\alpha)=1, T_{1}(\alpha)=\alpha$ and, for $n \geq 2$ :

$$
T_{n}(\alpha)=2 \alpha T_{n-1}(\alpha)-T_{n-2}(\alpha)
$$

As an example, those parameters of $8 \mathrm{kmol} \cdot \mathrm{m}^{-3} \mathrm{HNO}_{3}$ $\left(X=I_{x}^{1 / 2}=0.374\right)$ are shown in Table 3 .

From the above process, $\left[\mathrm{HNO}_{2}\right]$ is calculated from the measured $E$ in $\mathrm{HNO}_{3}$. The advantage of this method is that $a_{\mathrm{L}}$ and $\gamma_{ \pm}$can be calculated at various temperature and $\mathrm{HNO}_{3}$ concentration. Fig. 1 shows

Table $3 L_{2}, L_{1}, J_{2}$ and $J_{1}$ values of $8 \mathrm{kmol} \cdot \mathrm{m}^{-3} \mathrm{HNO}_{3}$.

\begin{tabular}{cccccc}
\hline$X_{1}$ & $X\left(I_{X}^{1 / 2}\right)$ & $L_{2}$ & $L_{1}$ & $J_{2}$ & $J_{1}$ \\
\hline 0.2799 & 0.3740 & 10911.16 & -1263.01 & 205.9 & -10.9512 \\
\hline
\end{tabular}




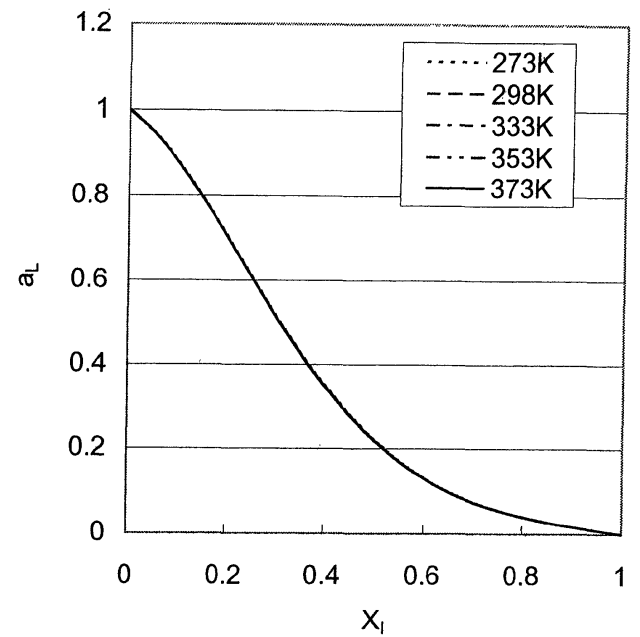

Fig. 1 Relationship between total mole fraction of ions $\left(X_{1}\right)$ and water activity $\left(a_{\mathrm{L}}\right)$ as a function of temperature.

the relationship between total mole fraction of ions $\left(X_{\mathrm{I}}\right)$ and water activity $\left(a_{\mathrm{L}}\right)$. From this result, $a_{\mathrm{L}}$ is hardly influenced by temperature. Fig. 2 shows the relationship between $X_{\mathrm{I}}$ and mean activity coefficient as a standard of molar fraction $\left(f_{ \pm, T}\right) . \Upsilon_{ \pm, T}$ can be calculated by equation (7). $\gamma_{ \pm, T}$ of representative nitric acid concentrations and temperatures are shown in Table 4.

\section{Experimental}

Electrochemical tests were performed to measure the redox potential $(E)$ of nitric acid solution and the corrosion potential of stainless steel $\left(E_{\text {corr }}\right)$ as a function of NO purging. The redox potential in $8 \mathrm{kmol}$. $\mathrm{m}^{-3} \mathrm{HNO}_{3}$ (i.e. the potential adopted by clean $\mathrm{Pt}$ ) was measured at $353 \mathrm{~K}$ and $373 \mathrm{~K}$ in this experiment. Corrosion potential measurements for stainless steel were made in $8 \mathrm{kmol} \cdot \mathrm{m}^{-3} \mathrm{HNO}_{3}$ at $373 \mathrm{~K}$, again as a function of NO purging. The stainless steel used was NAG (nitric acid grade) 18/10 L, manufactured in the United Kingdom. The composition of this steel is
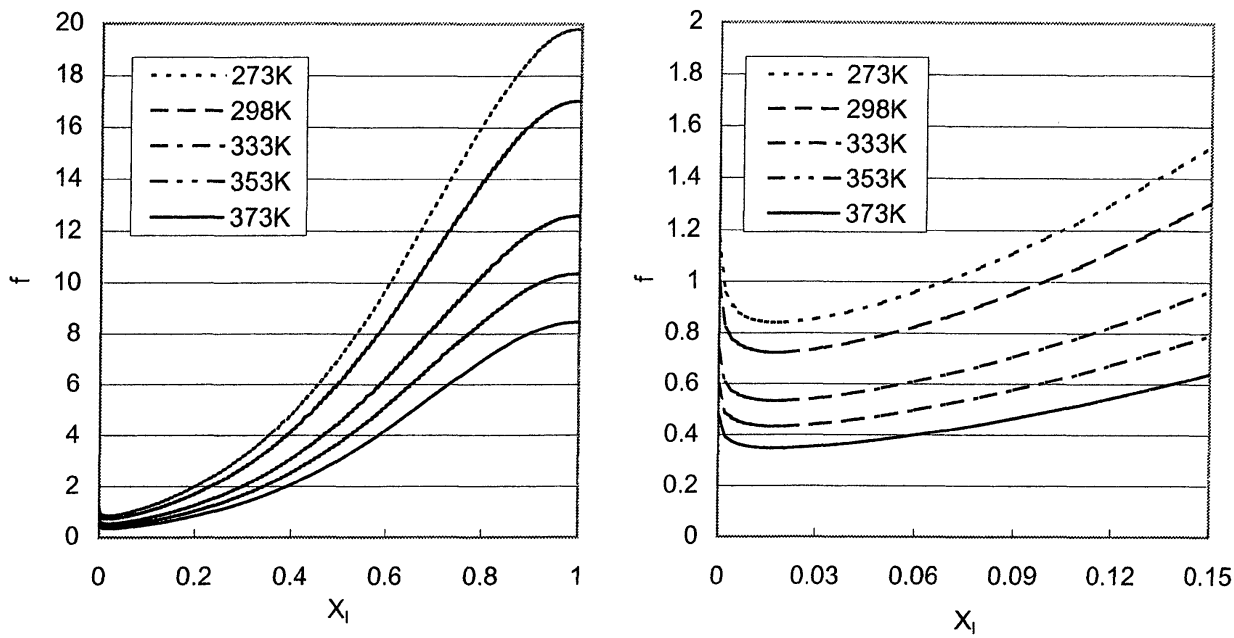

Fig. 2 Relationship between total mole fraction of ions $\left(X_{1}\right)$ and mean activity coefficient $(f)$ as a function of temperature.

Table $4 r_{ \pm, T}$ of representative $\mathrm{HNO}_{3}$ concentrations and temperatures.

\begin{tabular}{ccccccc}
\hline $\begin{array}{c}\mathrm{HNO}_{3} \text { concentration } \\
\left(\mathrm{kmol} \cdot \mathrm{m}^{-3}\right) \text { at 298K }\end{array}$ & 1.0 & 3.0 & 4.0 & 8.0 & 9.0 & 13.0 \\
\hline $\begin{array}{c}\text { Density } \\
{[\mathrm{kg} / \mathrm{l}] \text { at 298K }}\end{array}$ & 1.0302 & 1.0955 & 1.1270 & 1.2449 & 1.2709 & 1.3611 \\
\hline $\mathrm{X}_{1}$ & 0.03589 & 0.1065 & 0.1413 & 0.2799 & 0.3152 & 0.4633 \\
\hline$\gamma_{ \pm 273 \mathrm{~K}}$ & 0.8405 & 1.0844 & 1.2501 & 2.0818 & 2.3224 & 3.3217 \\
$\gamma_{ \pm 298 \mathrm{~K}}$ & 0.7216 & 0.9313 & 1.0738 & 1.7892 & 1.9962 & 2.8562 \\
$\gamma_{ \pm 333 \mathrm{~K}}$ & 0.5321 & 0.6873 & 0.7928 & 1.3226 & 1.4759 & 2.1132 \\
$\gamma_{ \pm 353 \mathrm{~K}}$ & 0.4336 & 0.5614 & 0.6481 & 1.0848 & 1.2114 & 1.7377 \\
$\gamma_{ \pm 373 \mathrm{~K}}$ & 0.3482 & 0.4528 & 0.5238 & 0.8821 & 0.9862 & 1.4198 \\
\hline $\mathrm{a}_{\mathrm{L} 298 \mathrm{~K}}$ & 0.9638 & 0.8679 & 0.8106 & 0.5546 & 0.4905 & 0.2645 \\
\hline
\end{tabular}


Table 5 Chemical composition of NAG18/10 L electrode.

\begin{tabular}{cccccccccc}
\hline $\mathrm{C}$ & $\mathrm{S}$ & $\mathrm{P}$ & $\mathrm{Si}$ & $\mathrm{Mn}$ & $\mathrm{Ni}$ & $\mathrm{Cr}$ & $\mathrm{Mo}$ & $\mathrm{V}$ & $\mathrm{Cu}$ \\
\hline 0.015 & 0.008 & 0.015 & 0.32 & 1.54 & 9.64 & 18.77 & 0.03 & 0.07 & 0.03 \\
\hline $\mathrm{Sn}$ & $\mathrm{Al}$ & $\mathrm{Ti}$ & $\mathrm{Co}$ & $\mathrm{B}$ & $\mathrm{N}$ & $\mathrm{As}$ & $\mathrm{Nb}$ & $\mathrm{W}$ & $\mathrm{Fe}$ \\
\hline 0.008 & 0.008 & $<0.01$ & 0.04 & 0.0005 & 0.044 & 0.007 & $<0.01$ & 0.04 & bal \\
\hline & & & & & & & & & wt\%
\end{tabular}

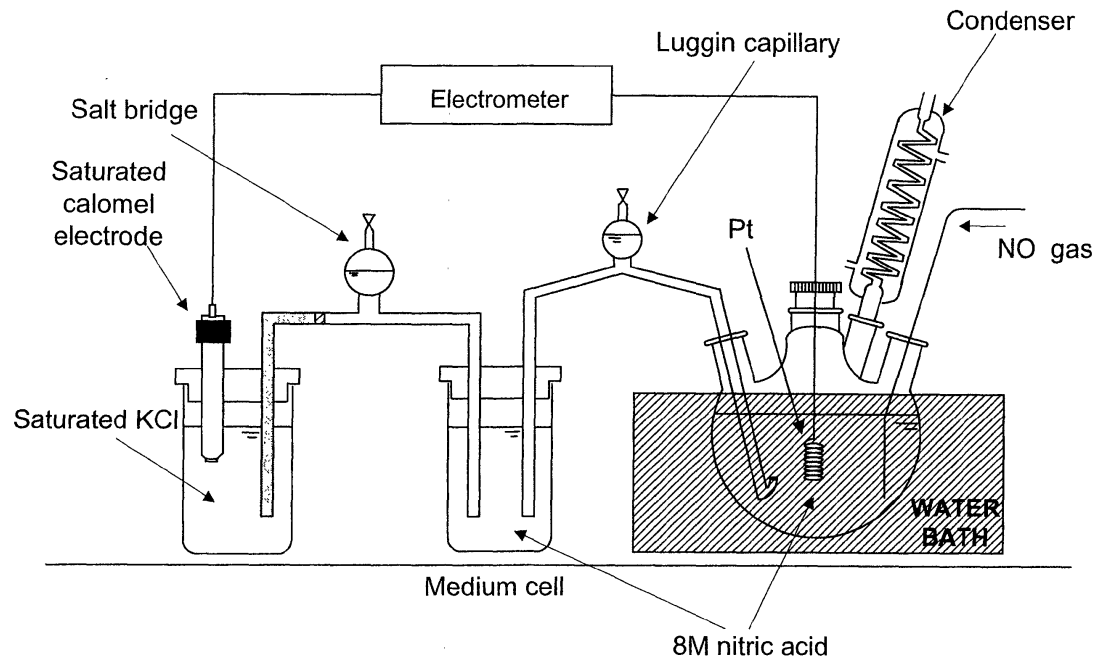

Fig. 3 Basic structure of electrochemical test.

given in Table 5 and it can be seen that it is closely related to AISI 304L.

The basic structure of electrochemical test is shown in Fig. 3. A Pt coil was used as working electrode. The electrochemical test cell was immersed in a thermostatically-controlled water bath which was adjusted to maintain the desired temperature in the test liquor as measured by a PTFE-coated thermocouple immersed in it. The desired purge gas was supplied to the test liquor via microbore PTFE tubing and the gas flowrate was regulated by a stainless steel flowmeter. NO flow rate was adjusted at $10 \mathrm{~cm}^{3} / \mathrm{min}$ in this work. The test vessel was open to the atmosphere via a water-cooled condenser and the purge gas was vented to an operating fume cupboard. The reference electrode was a Saturated Calomel (SCE) which was connected to the test liquor by a series of Luggin capillaries designed to prevent $\mathrm{Cl}^{-}$contamination of test liquor and nitrite contamination of the SCE. The Luggin capillaries were threaded with glass-fibre string in order to prevent loss of electrolytic connection due to solution off-gassing. The technical grade of pure NO was used for this test.

From the redox potential measured as a function of time, $\left[\mathrm{HNO}_{2}\right]$ was calculated on the basis of equation (2). The analysis was performed in the range from 0.88 to 0.97 [V vs. SCE] at $353 \mathrm{~K}$ and 0.915 to 0.98 [V vs. SCE] at $373 \mathrm{~K}$ to determine the relationship between redox potential and $\mathrm{HNO}_{2}$ concentration.
Table 6 Measurement results of $\mathrm{HNO}_{2}$ concentration by colourimetric method at $353 \mathrm{~K}$.

\begin{tabular}{|c|c|c|}
\hline $\begin{array}{c}E_{\mathrm{SCE}} \\
\text { Vvs SCE] }\end{array}$ & $\begin{array}{c}E_{\mathrm{NHE}} \\
\text { Nvs NHE] }\end{array}$ & $\begin{array}{c}\text { Mea.[HNO } \\
{[\mathrm{mg} / \mathrm{l}]}\end{array}$ \\
\hline 0.89 & 1.0947 & 9200 \\
\hline 0.9 & 1.1047 & 5200 \\
\hline 0.91 & 1.1147 & 2800 \\
\hline 0.92 & 1.1247 & 1600 \\
\hline 0.93 & 1.1347 & 800 \\
\hline 0.94 & 1.1447 & 400 \\
\hline 0.95 & 1.1547 & 210 \\
\hline 0.96 & 1.1647 & 85 \\
\hline 0.97 & 1.1747 & 31 \\
\hline 0.98 & 1.1847 & 17 \\
\hline
\end{tabular}

The adjustment of redox potential in this experiment was not difficult. The desirable potential can be chosen because it increases automatically by stopping NO. The actual $\left[\mathrm{HNO}_{2}\right]$ resulting in the solution was determined by a Colourimetric method using Cleve's acid ${ }^{6}$ in order to allow comparison with the calculated $\mathrm{HNO}_{2}$ concentration. This method employs an initial dilution by a factor of one hundred and is thus suitable for determining $\mathrm{HNO}_{2}$ in initially hot and concentrated nitric acid solutions. 
Table 7 Measurement results of $\mathrm{HNO}_{2}$ concentration by colourimetric method at $373 \mathrm{~K}$.

\begin{tabular}{|c|c|c|}
\hline$E_{S C E}$ & $E_{N H E}$ & Mea. $\left[\mathrm{HNO}_{2}\right]$ \\
\hline [V vs SCE] & [V vs NHE] & {$[\mathrm{mg} / \mathrm{l}]$} \\
\hline 0.925 & 1.1135 & 2600 \\
\hline 0.93 & 1.1185 & 1900 \\
\hline 0.94 & 1.1285 & 1000 \\
\hline 0.95 & 1.1385 & 500 \\
\hline 0.96 & 1.1485 & 240 \\
\hline 0.97 & 1.1585 & 120 \\
\hline 0.98 & 1.1685 & 50 \\
\hline 0.99 & 1.1785 & 20 \\
\hline
\end{tabular}

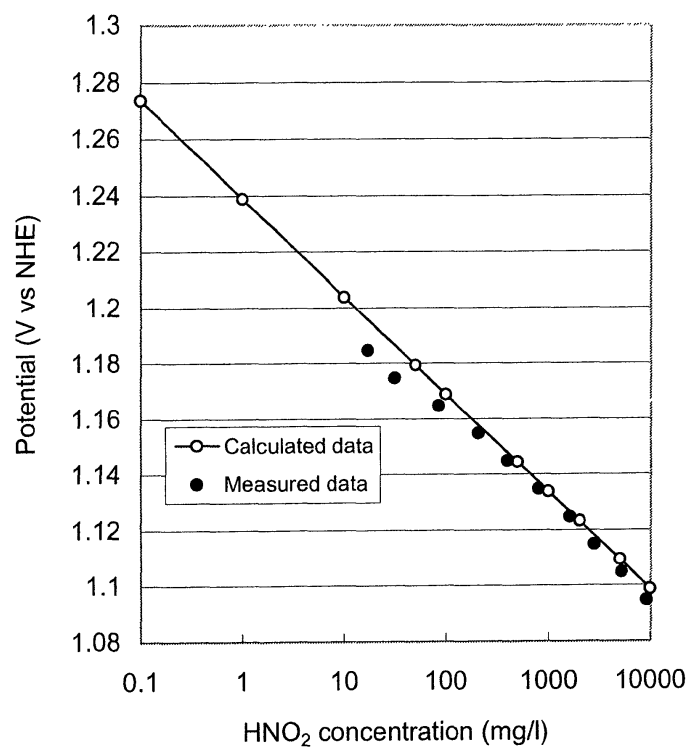

Fig. 4 Effect of $\mathrm{HNO}_{2}$ concentration on redox potential of $8 \mathrm{kmol} \cdot \mathrm{m}^{-3} \mathrm{HNO}_{3}$ at $353 \mathrm{~K}$.

\section{Results and discussion}

First of all, the reasonability of the calculation process is discussed by comparing measured data. Tables 6 and 7 show the measured values of $\mathrm{HNO}_{2}$ concentration obtained by the Colourimetric method. Figs. 4 and 5 compare the calculated values of $\mathrm{HNO}_{2}$ with the measured ones. Consequently, the agreement between the calculated and measured data is good and this calculation process based on Nernst's equation applying calculated activity coefficients is useful to follow the change of $\left[\mathrm{HNO}_{2}\right]$. Also, it is roughly considered that the effect of temperature on the thermodynamic data is correctly discussed in the calculation process. The error of calculated value to measured one was within $30 \%$ for $\left[\mathrm{HNO}_{2}\right]>50 \mathrm{ppm}$. For lower $\mathrm{HNO}_{2}$ concentrations, it is considered that the colourimetric technique used to measure $\mathrm{HNO}_{2}$ was not sufficiently sensitive and hence that some

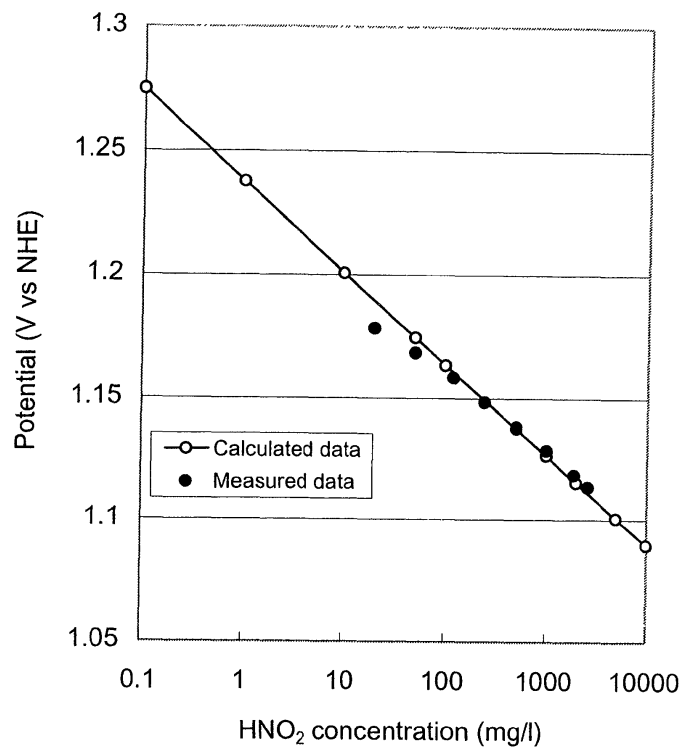

Fig. 5 Effect of $\mathrm{HNO}_{2}$ concentration on redox potential of $8 \mathrm{kmol} \cdot \mathrm{m}^{-3} \mathrm{HNO}_{3}$ at $373 \mathrm{~K}$.

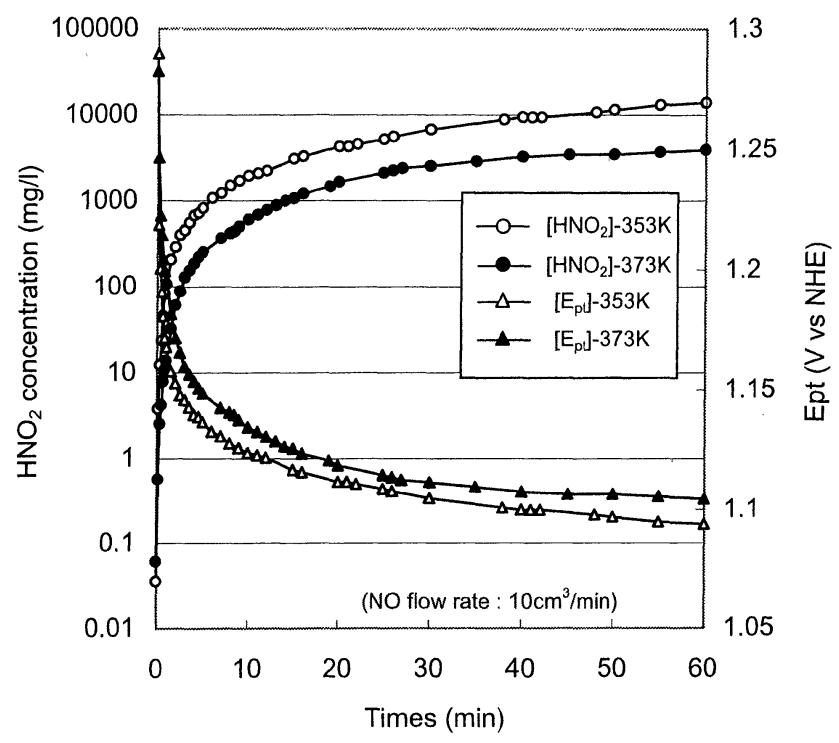

Fig. 6 Change of Redox potential and $\mathrm{HNO}_{2}$ concentration calculated from it in $8 \mathrm{kmol} \cdot \mathrm{m}^{-3} \mathrm{HNO}_{3}$ under $\mathrm{NO}$ bubbling

improvement could be made here.

Fig. 6 shows the change of redox potential with NO bubbling and $\left[\mathrm{HNO}_{2}\right]$ calculated from these potentials. The relationship between $E_{\mathrm{SCE}}$ and $E_{\mathrm{NHE}}$ was calibrated by the following equation as a function of temperature from the data presented in Table $8^{7)}$.

$$
E_{\mathrm{NHE}}=E_{\mathrm{SCE}}+0.3522-10^{-6} T(T+63.7)
$$$$
[283 \mathrm{~K} \leq T \leq 313 \mathrm{~K}]
$$

where $T(\mathrm{~K})$ is the temperature of the saturated $\mathrm{KCl}$ solution for $\mathrm{SCE}$.

The redox potential of $8 \mathrm{M} \mathrm{HNO}$ is lowered and $\mathrm{HNO}_{2}$ concentration increased by $\mathrm{NO}$ bubbling from the Fig. 6. This means that NO acts as a reducing 
Table 8 Standard half-cell potentials as a function of temperature in absolute volts.

\begin{tabular}{|c|c|}
\hline Temperature $(\mathrm{K})$ & Saturated KCl $(\mathrm{V})$ \\
\hline 273 & 0.2602 \\
\hline 283 & 0.2541 \\
\hline 288 & 0.2509 \\
\hline 293 & 0.2477 \\
\hline 298 & 0.2444 \\
\hline 303 & 0.2411 \\
\hline 308 & 0.2377 \\
\hline 311 & 0.2357 \\
\hline 313 & 0.2343 \\
\hline 323 & 0.2272 \\
\hline 333 & 0.2199 \\
\hline 343 & 0.2124 \\
\hline 353 & 0.2047 \\
\hline 363 & 0.1967 \\
\hline 373 & 0.1885 \\
\hline
\end{tabular}

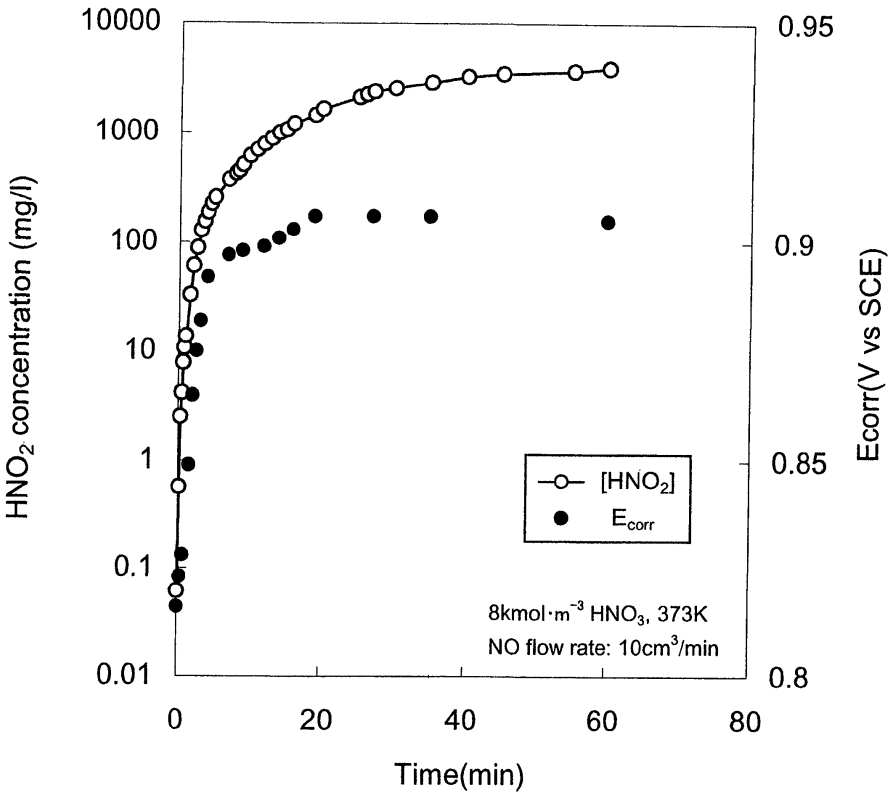

Fig. 7 Effect of $\mathrm{HNO}_{2}$ concentration on corrosion potential of NAG18/10 L.

course applicable only to the simple $\mathrm{HNO}_{3}-\mathrm{H}_{2} \mathrm{O}$ system, but can be applied over the range from $273 \mathrm{~K}$ to $373 \mathrm{~K}$ for $0 \%-100 \% \mathrm{HNO}_{3}$.

$\mathrm{HNO}_{2}$ increases the corrosion potential of stainless steel and hence has a significant effect on nitric acid corrosion.

\section{References}

1) K. J. Vetter: "Electrochemical kinetics-theoretical and experimental aspects", Academic Press, New York, p.490 (1967).

2) A.B. McIntosh and T.E. Evans : Proc. $2^{\text {nd }}$ Int. Conf. On Peaceful Uses of Atomic Energy, p.206-225 (1958).

3) M. Pourbaix : "Atlas of electrochemical equilibria in aqueous solutions", NACE, Houston (1974).

4) "Computer-Calculated Potential pH Diagrams to $300^{\circ} \mathrm{C}$ ", EPRI NP-3137-Vol. 2 (1983).

5) S.L. Clegg and P. Brimblecombe: J. Phys. Chem., 94 5369-5380 (1990).

6) L.C. Thomas and G.J. Chamberlin: "Colorimetric chemical analytical methods", $9^{\text {th }}$ Edition, the Tintometer Ltd, Salisbury, p.281, (1980).

7) D.J. G. Ives and G. J. Janz: "Reference Electrodes" (1961).

(Manuscript received May 7, 2002 ; in final form September 2, 2002) 